$\begin{gathered}\text { Науковий вісник НЛТУ України } \\ \text { Scientific Bulletin of UNFU } \\ \text { https://nv.nltu.edu.ua }\end{gathered}$
$\begin{gathered}\text { https://doi.org/10.36930/40300116 } \\ \text { Article received 03.02.2020 p. }\end{gathered}$
$\begin{aligned} & \text { Article accepted 27.02.2020 p. } \\ & \text { ISSN 2519-2477 (online) }\end{aligned}$
UDK 338.486.5:005.21
Correspondence author
I. I. Svydruk

Ю. Б. Миронов, І. І. Свидрук, М. Я. Топорницька

Львівський торговельно-економічний університет, м. Львів, Украӥна

\title{
СТРАТЕГІЧНЕ МАРКЕТИНГОВЕ ПЛАНУВАННЯ В ТУРИЗМІ
}

Розглянуто роль маркетингу під час розроблення та виконання стратегічного бізнес-плану організації, висвітлено структуру типового бізнес-плану туристичного підприємства, акцентовано увагу на головних вимогах до бізнес-планування. За умов глобалізації та креативізації економіки, гіперконкуренції й глибоких метаморфоз, які відбуваються у сутності та змісті бізнесу, стає очевидним, що важливим чинником успішного функціонування сучасної туристичної організації $\epsilon$ іiї забезпечення адекватною системою стратегічного маркетингового планування. Відтак охарактеризовано процес формування стратегії маркетингу у туристичному бізнесі та його етапи. Обгрунтовано доцільність застосування у туристичному бізнесі маркетингової моделі розроблення та просування туристичного продукту "7Р". Відповідно до цього вважається, що якісний туристичний продукт розробляється на основі досліджень попиту споживачів, пропонується у потрібному місці, адресно скеровується конкретним сегментам споживачів, за привабливими цінами, грамотно та професійно видається на ринку туристичних послуг та реалізується з якісним обслуговуванням. Цього можна досягти завдяки чіткій та послідовній стратегічній програмі маркетингу. Стратегічна програма маркетингу туристичного підприємства насамперед повинна відображати попит та конкурентну ситуацію на ринку й описувати негайні заходи на випадок їх зміни. Професійно розроблена стратегія маркетингу дає змогу туристичним компаніям протидіяти різним впливам зовнішнього середовища у довготерміновому періоді. Відповідно до цього виокремлено принципи формування стратегії маркетингу туристичної компанії. Вивчено можливості збільшення прибутковості туристичної компанії у контексті реалізації стратегії маркетингового планування. Визначено значення позиціювання туристичного продукту на ринку туристичних послуг під час формування стратегії маркетингу в туризмі. Запропоновано дієві методи контролю реалізації упровадженої стратегії. Визначено перспективні шляхи подальших наукових досліджень у цьому напрямі.

Ключові слова: туризм; стратегія; бізнес-план; стратегічне маркетингове планування.

Вступ. Сучасна українська індустрія туризму характеризується, на жаль, як сфера економіки, орієнтована переважно на вивіз капіталу. Наявний стан у сфері туризму посилюється також загальними проблемами економічного та соціального характеру, що істотно обмежує в'їзні потоки туристів і веде до економічних втрат.

Економіко-соціальна криза останніх років серйозно вплинула на розвиток туристичної галузі, викликавши потребу якісних змін і вдосконалення структури туристичної галузі, підвищення ефективності управління та якості послуг. Особливої актуальності набувають при цьому питання щодо вдосконалення системи стратегічного маркетингового планування в туристичній організації, що дає змогу сконцентрувати наявні обмежені ресурси на найважливіших стратегічних напрямах, забезпечити гнучкість і маневреність їх використання. Забезпечення конкурентоспроможності організації є неможливим без розробки та реалізації ефективної маркетингової стратегії розвитку. Саме тому тема дослідження $є$ надзвичайно актуальною та своєчасною.
Об'єктом дослідження є підприємства сфери туризму, а предметом - процес стратегічного маркетингового планування.

Метою роботи є дослідження теоретичних основ стратегічного маркетингового планування в туризмі, розкриття його місця та технологічних особливостей у системі управління туристичною компанією, обгрунтування необхідності його вдосконалення на сучасному етапі господарювання.

Відповідно до мети роботи сформульовано такі основні завдання дослідження:

- визначити роль маркетингу під час розроблення та виконання стратегічного бізнес-плану організації;

- охарактеризувати процес формування стратегії маркетингу у туристичному бізнесі та його етапи;

- виокремити принципи формування стратегії маркетингу туристичної компанії;

- з'ясувати сутність позиціонування туристичного продукту на ринку туристичних послуг під час формування стратегії маркетингу в туризмі.

Матеріал і методи дослідження. Теоретичною і ме-

\section{Інформація про авторів:}

Миронов Юрій Богданович, канд. екон. наук, доцент, кафедра туризму та готельно-ресторанної справи.

Email: yuriy@myronov.com; https://orcid.org/0000-0002-9015-506X

Свидрук Ірена Ігорівна, д-р екон. наук, професор, кафедра менеджменту.

Email: irena_svidruk@ukr.net; https://orcid.org/0000-0002-3099-6449

Топорницька Марія Ярославівна, канд. географ. наук, доцент, кафедра туризму та готельно-ресторанної справи. Email: Topornytska_maria@i.ua; https://orcid.org/0000-0001-8876-5857

Цитування за ДСТУ: Миронов Ю. Б., Свидрук І. І., Топорницька М. Я. Стратегічне маркетингове планування в туризмі. Науковий вісник НЛТУ України. 2020, т. 30, № 1. С. 94-98.

Citation APA: Myronov, Yu. B., Svydruk, I. I., \& Topornytska, M. Ya. (2020). Strategic marketing planning in tourism. Scientific Bulletin of UNFU, 30(1), 94-98. https://doi.org/10.36930/40300116 
тодологічною основою дослідження є досягнення теорії менеджменту, маркетингу, економічної теорії, праці вітчизняних та закордонних авторів у галузі туризму. У процесі дослідження застосовували методи синтезу, аналізу, індукції, дедукції, наукового абстрагування, моделювання.

Аналіз літературних джерел. Проблематику дослідження окремих аспектів вдосконалення управління i маркетингового планування розвитку в сфері туризму відображено в роботах таких авторів, як: К. Барроу [2], I. Ванєєва, Н. Тіхонова [12], Р. Гарифуллина, Ф. Сафин [3], А. Рябцев [9], Р. Сіркіс, С. Рейс [10] та багатьох інших. Водночас, недостатня розробленість теоретичних i методичних основ стратегічного маркетингового планування у туристичних організаціях, а також рекомендацій щодо організаційного, економічного та інформаційного забезпечення процесу планування істотно знижують ефективність вжитих заходів у цій галузі національної економіки.

Результати дослідження. Роль маркетингу за останні десятиріччя істотно зросла. Посилення конкуренції у глобальному масштабі охопило багато видів бізнесу. Різко збільшився попит на специфічні туристичні послуги. А існувати та розвиватись у динамічному ринковому середовищі стало складним завданням без здійснення професійної маркетингової діяльності. Отже, останнім часом зросла роль маркетингу в розробці та виконанні стратегічного бізнес-плану.

Стратегічний маркетинг за своєю сутністю $є$ інноваційним. Його рішення формуються на основі всебічної діагностики проблем і концептуалізації пропонованих альтернатив. Стратегічний маркетинг, за визначенням Жан-Жака Ламбена, - це "систематичний і постійний аналіз потреб ключових груп споживачів, а також розроблення концепцій ефективних товарів і послуг, що забезпечують їх виробнику конкурентне стійке становище" [5]. Оперативний (тактичний) маркетинг більш утилітарний та спрямований на організацію збуту, політику комунікації для інформування потенційних покупців (туристів) та демонстрацію особливостей чи переваг туристичного продукту. Обидва підходи до маркетингу доповнюють один одного та втілюються в єдиній маркетинговій політиці туристичного підприємства. Якщо використання методів тактичного маркетингу дає змогу ефективно вирішувати поточні завдання реалізації туристичних послуг, забезпечуючи цим самим короткотермінову комерційну рентабельність діяльності туристичного підприємства, то стратегічний маркетинг здатний виробити довготермінову перспективну програму 3 урахуванням стану і динаміки всіх компонентів ринку.

Специфіка стратегічного маркетингу в сфері туризму визначається:

- залежністю від зовнішніх чинників;

- особливостями туристичного продукту (і послуг, які його формують);

- технологіями виробництва й споживання туристичного продукту;

- поліструктурністю об'єкта;

- складністю вирішуваних завдань [3].

Планування можна вважати ключовим елементом успіху будь-якого нового бізнесу. Бізнес-план - це документ, який відображає завдання підприємства як коротко-, так і довготермінові, містить опис продуктів або послуг, які пропонуються, опис вірогідної кон'юнктури ринку цих продуктів, інформацію про ресурси та засоби, які будуть залучатися для виконання завдань $з$ огляду на ймовірну конкуренцію.

Бізнес-плани відрізняються за своєю структурою та розмірами. Типовий бізнес-план орієнтовно складається з таких розділів: резюме; опис товарів та послуг; ринки збуту продукції; конкуренція на ринках збуту; план маркетингу; план виробництва; організаційний план; правове забезпечення діяльності фірми; оцінка ризиків та страхування; фінансовий план; стратегія фінансування [2]. Перераховані розділи є лише опорною схемою складання бізнес-планів і можуть відрізнятись у різних випадках назвами та послідовністю.

Стратегічне бізнес-планування в туризмі відповідає на два глобальні запитання: якою $є$ реальна мета бізнесу та які заходи варто зреалізувати заради їі досягнення. Плануванню передує прогнозування як діяльність щодо виявлення альтернативних перспективних напрямів розвитку підприємства сфери туризму, а також реальних термінів досягнення планових показників. Прогнозування за умов динамічного, мінливого зовнішнього середовища $є$ необхідною складовою бізнес-планування. Якісна його реалізація потребує від менеджерів уміння аналізувати бюджети, оцінювати стан галузі та економіки загалом, володіння аналітичними навичками, здатностями впроваджувати інноваційні методи управління.

Бізнес-план туристичного підприємства розрахований також на потенційних інвесторів чи кредиторів для фінансування цього проекту. Він також повинен запевнити власника підприємства та його партнерів у тому, що їхні наміри можливо втілити у дійсність і вони $є$ потенційно вигідними. У кризових ситуаціях без бізнесплану підприємство індустрії туризму змушене вживати відповідні заходи, а не ефективно управляти.

У процесі розроблення бізнес-плану менеджерам туристичного підприємства варто зосередити свою увагу на включенні всіх головних стратегічних заходів, реалізація яких допоможе забезпечити успіх. У майбутньому бізнес-план зможе бути планом дій у практичній роботі. Досконало складений бізнес-план є одним із гарантів успіху в туристичному бізнесі. У процесі розроблення та вже реалізації бізнес-плану часто виявляються його недоліки та слабкі сторони.

Важливо, щоб бізнес-план був реалістичним і наведена в ньому інформація добре висвітлювала наміри його укладачів. У протилежному випадку неточна чи неповна інформація може оцінюватись потенційними інвесторами (кредиторами) як невідповідна до дійсності, внаслідок чого вони можуть відмовитись від участі у проекті. 3 метою забезпечення акуратності та повноцінності бізнес-плану необхідною є наявність реальної інформації, що дає змогу менеджерам компанії або окремого підприємства приймати адекватні рішення. Через неточну інформацію керівництво може приймати неефективні рішення [8].

Бізнес-плани можуть відрізнятися своїми розмірами, але необхідною умовою $\epsilon$ наявність достатньої інформації. 3 огляду на цю умову, особливої уваги заслуговує вивчення ринку, яке забезпечить необхідну інформаційну основу для бізнес-планування. Маркетингові дослідження на етапі бізнес-планування дають змогу визначити стратегії управління життєвим циклом туристичного продукту, ціноутворенням, стимулюванням 
продажу та каналами збуту. Це найповніше виражається стандартним комплексом дій, що отримав у спеціальній літературі назву "маркетинг-мікс" (marketing mix) або "4Р". Складовими цієї моделі, згідно з Аленом Андертоном [1], $є$ :

1) product - туристичний продукт;

2) price - ціни, ціноутворення;

3) promotion - просування, реклама;

4) place - місце, тобто канали розповсюдження.

Однак, у туристичному бізнесі, на думку авторів, доцільно слідувати послідовності маркетингових заходів, яка представлена модифікованою моделлю "7Р" (рис. 1).

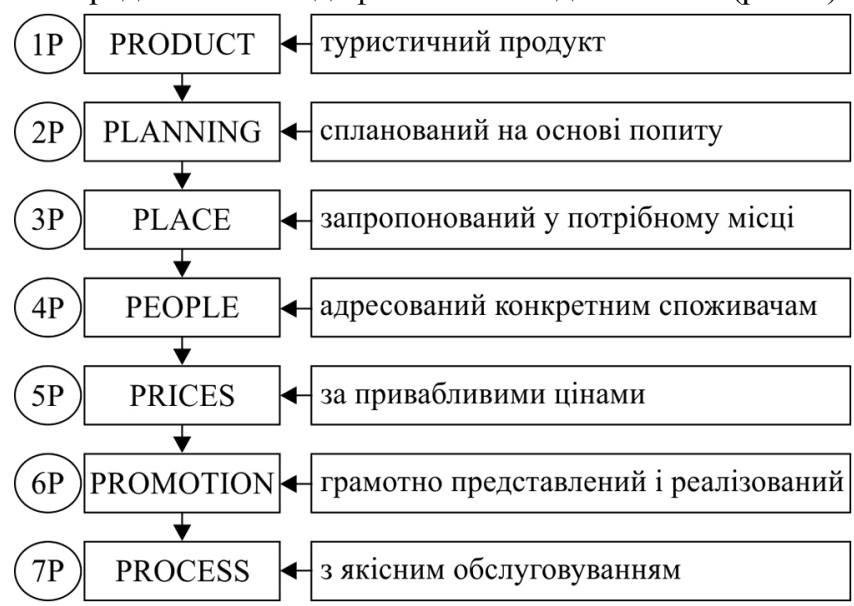

Рис. 1. Модель "Сім Р" розробки туристичного продукту [4]

Відповідно до цього вважається, що якісний туристичний продукт обов'язково має бути розроблений на основі досліджень попиту споживачів, запропонований у потрібному місці, адресно скерований конкретним сегментам споживачів, за привабливими цінами, гра- мотно та професійно представлений і реалізований 3 якісним обслуговуванням. Цього можна досягти за наявності чіткої та послідовної стратегічної програми маркетингу. Стратегічна програма маркетингу підприємства туристичної індустрії насамперед повинна відображати попит та конкурентну ситуацію на ринку й описувати негайні заходи на випадок їх зміни. Професійно розроблена стратегія маркетингу дає змогу туристичним компаніям протидіяти різним впливам зовнішнього середовища у довготерміновому періоді.

Під час розроблення стратегії маркетингу підприємства туристичної галузі потрібно враховувати такі важливі аспекти:

- визначення цілей бізнесу;

- вивчення внутрішнього та зовнішнього середовища;

- виявлення можливостей та наявних ресурсів для ведення бізнесу;

- формування цілей маркетингу;

- розроблення стратегії досягнення цих цілей;

- створення інформаційних систем та баз даних.

Схематично процес формування стратегії маркетингу туристичної компанії представлено на рис. 2. Стратегія в індустрії туризму, на думку професора С. Калвера (Великобританія), пов'язана 3 двома істотними індикаторами в економіці - рівнем ділової активності та часткою доходів споживачів, що виділяється на відпочинок. Найбільше залежні від цих індикаторів великі компанії, які структурно складаються 3 менших підприємств. Тому в такому випадку необхідна як централізована стратегія, так і індивідуальний підхід, оскільки стандартизований туристичний продукт не обов'язково підійде навіть однаковим сегментам споживачів різних регіонів [11].

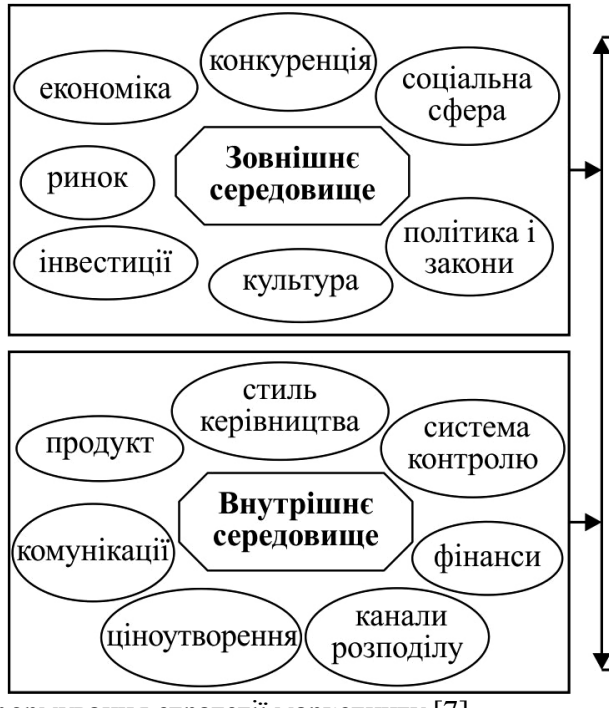

Рис. 2. Процес формування стратегії маркетингу [7]

Учені Р. Сіркіс та С. Рейс виділяють 5 принципів, за допомогою яких підприємства туристичної індустрії можуть формувати свою стратегію маркетингу:

1) ідентифікація стратегічних центрів організації;

2) формування стратегії засновується на інформаційній базі даних;

3) вид діяльності не вибирається навмання, його успіх залежить від вимог ринку;

4) стратегічні альтернативи є обмеженими;

5) велике значення мають зовнішні чинники [10].

Процес формування стратегії у туристичному бізнесі починається $з$ аналізу взаємовідносин між спожива-

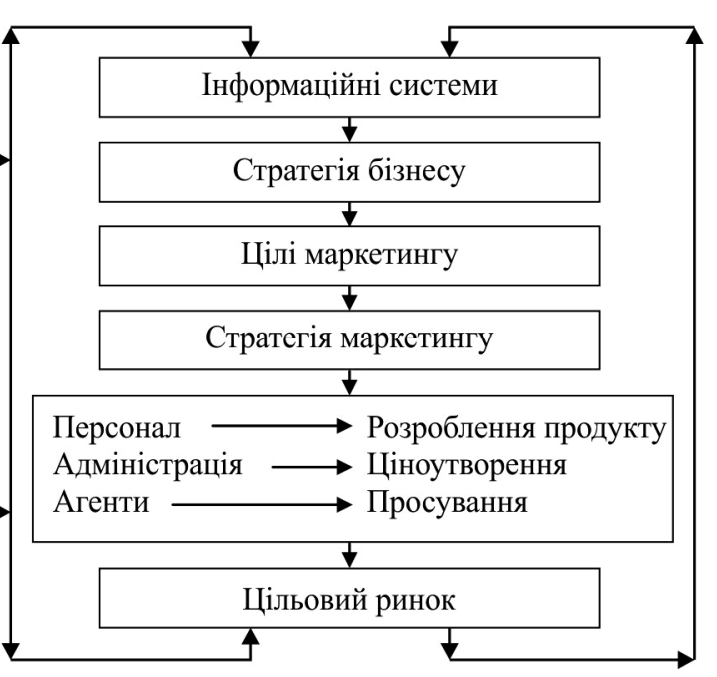

чами та продуктом з одного боку та конкурентним ринковим середовищем - 3 іншого. У разі серйозного підходу до справи використовуються методи математичного програмування та статистичний інструментарій.

Наступним етапом у процесі формування стратегії маркетингу $\epsilon$ вивчення можливостей приросту прибутку. Цього можна досягнути шляхом розширення кількості споживачів та ринків, збільшення продуктивності праці, зниження витрат виробництва та продажу.

Важливим моментом під час формування стратегії можна також вважати позиціювання туристичного продукту на ринку. Позиціювання - це дії по розміщення 
туристичного продукту (послуги) на визначеному ринку, який називають цільовим туристичним ринком, 3 метою забезпечення конкурентоспроможності туристичного продукту (послуги). На думку західного вченого Р. Левіса [6], позиціювання має залежати від вимог та побажань клієнтів, іміджу компанії, обіцяних переваг. Успішне позиціювання можна здійснити за допомогою вміло організованої комунікаційної політики 3 використанням прийомів реклами та паблік рилейшнз.

Ще однією істотною проблемою під час розроблення стратегії маркетингу, на погляд С. Калвера, є нагляд за якістю обслуговування. У туристичному бізнесі взаємовідносини між персоналом та клієнтами є властивістю самого продукту. Тому вони стають частиною процесу планування [11].

У процесі реалізації стратегії варто, на нашу думку, приділити значну увагу контролю упровадженої стратегії. Можна запропонувати такі методи контролю:

- оцінювання прибутків (збитків);

- аналіз коефіцієнтів фінансово-господарської діяльності;

- проведення аудиту;

- маркетингові дослідження окремих продуктів та ринків;

- моніторинг (опитування) споживачів.

Заключним етапом стратегічного планування маркетингу є розроблення плану маркетингу підприємства. План маркетингу представляє собою документ, розроблений на тривалий період (декілька років, залежно від специфіки підприємства та компетентності розробників), який орієнтує діяльність в індустрії туризму та визначає механізм дій підприємства після виявлення змін, спричинених зовнішніми та внутрішніми чинниками [5].

Важливість вивчення середовища в туристичному бізнесі зумовлена його мінливістю та посиленою конкуренцією. План маркетингу, на відміну від стратегії, містить тактичні складові, що стосуються специфіки окремих видів маркетингової діяльності, а саме: просування, розподілу та продажу. 3 цього приводу професор С. Калвер стверджує, що стратегічний план можна розглядати як основу для плану маркетингу [11].

Під час розроблення плану маркетингу підприємства індустрії туризму потрібно визначити:

- термін, на який проводиться планування;

- вид продукту, для якого розробляється план;

- сегмент ринку, на який спрямований план.

Різні підприємства туристичної галузі можуть і будуть мати відмінні за обсягом та структурою плани, проте в них завжди є спільні компоненти:

- місія туристичного підприємства, напрями його діяльності;

- цілі фірми щодо ринку (частка ринку, обсяги продажу), фінансові цілі (прибутки, витрати) та інші (імідж на ринку);

- аналіз зовнішнього середовища (характеристика індустрії; розмір ринку, економічні, політичні та соціальні чинники);

- аналіз внутрішнього середовища (наявні ресурси, оцінка минулих маркетингових стратегій, аналіз продуктів та послуг, іміджу туристичного підприємства);

- стратегія маркетингу (сегментація, позиціювання, проникнення на ринок);

- тактична програма (розроблення продукту, ціноутворення, просування, розподіл, відповідальні за це особи);

- виділення ресурсів (капіталу, людей, інформаційних систем) для виконання плану маркетингу;

• оцінка та контроль діяльності персоналу [7]
Маркетингове планування завжди було важливим питанням у розвитку й успішному існуванні туристичного підприємства. I саме воно, - планування, стане одним із найважливіших інструментів під час управління, якщо компанія продовжить боротьбу за вихід на ринок туристичних послуг з новими товарами та пропозиціями. Кінцеві цілі діяльності організацій індустрії туризму можуть бути різними: залучення в регіон більшої кількості туристів, завоювання частки ринку, збільшення прибутків тощо. Однак, досягнення цих цілей за умов ринкової конкуренції $є$ неможливим без маркетингової діяльності, яка є способом ведення бізнесу, сфокусованим на клієнті.

За умов глобалізації та креативізації економіки, гіперконкуренції й глибоких метаморфоз, які відбуваються у сутності та змісті бізнесу, стає очевидним, що важливим чинником успішного функціонування сучасної туристичної організації є іï забезпечення адекватною системою стратегічного маркетингового планування.

Висновки. Однією з умов успішності підприємства індустрії туризму на ринку є розроблення досконалого стратегічного бізнес-плану, головною складовою частиною якого $є$ планування маркетингу. У цьому напрямі важливо чітко визначити цілі туристичного підприємства та розробити програми їх досягнення на основі аналізу можливостей компанії та ринку туристичних послуг. Не менш важливим $є$ поточне короткотермінове планування, що відображає докладні механізми дій і дає можливість менеджерам ефективно управляти за умов мінливого ринкового середовища.

Потребує всебічного подальшого вивчення проблема комплексного представлення методології формування та чіткого механізму впровадження системи стратегічного планування на підставі сучасних принципів маркетингу у діяльність туристичних підприємств.

\section{References}

1. Anderton, A., \& Jones, R. (2007). GCSE Business Studies. (3rd ed.). Pearson Education Limited, $256 \mathrm{p}$.

2. Barrow, C., Barrow, P., \& Brown, R. (2018). The Business Plan Workbook: A Step-By-Step Guide to Creating and Developing a Successful Business. (9th ed.). London, Kogan Page Ltd., 376 p.

3. Garifullina, R. S., \& Safin, F. M. (2017). Strategic Tourism Marketing. Vestnik Kazanskogo gosudarstvennogo universiteta kultury i iskusstv, 2, 60-64. [In Russian].

4. Ilyina, E. N. (2014). Tour Operating: Activity Organization. (2nd ed.). Moscow: Finansy i statistika, 241 p. [In Russian].

5. Lambin, J.-J. (1996). Strategic Marketing Management. McGrawHill, $720 \mathrm{p}$.

6. Levis, R. S. (1981). The Positioning Statement for Hotels. https://doi.org/10.1177/001088048102200111

7. Papiryan, G. A. (2000). International Economic Relations: Marketing in Tourism. Moscow: Finansy i statistika, 160 p. [In Russian].

8. Papiryan, G. A. (2000). Management in the Hospitality Industry (hotels and restaurants). Moscow: Ekonomika, 207 p. [In Russian].

9. Riabtsev, A. A. (2008). Strategic Planning of Tourism Activities as a Basis for the Industrys Safe Development. Izvestiia RPGU im. A. I. Hertsena, 54, 185-188. [In Russian].

10. Sirkis, R. L., \& Race, S. M. (1981). Principles, Strategic Planning for the Food-Service Firm. Cornell HRA Quarterly, 22(1), 35-41.

11. Teare, R., Calver, S., Mazanec, J., \& Crawford-Welch, S. (1994). Marketing in Hospitality and Tourism: a Consumer Focus. London, NY, Cassel, 312 p.

12. Vaneieva, I. V., \& Tikhonova, N. I. (2004). Strategic Planning in the Tourism Industry. Kultura narodov Prichernomoria, 55(3), 15-17. [In Russian]. 
Yu. B. Myronov, I. I. Svydruk, M. Ya. Topornytska

Lviv University of Trade and Economics, Lviv, Ukraine

\section{STRATEGIC MARKETING PLANNING IN TOURISM}

The paper considers the role of marketing in the development and execution of the strategic business plan of the organization, highlights the structure of a typical business plan of a tourist company, and focuses on the main requirements for business planning. The study used methods of synthesis, analysis, induction, deduction, modeling, and technical and economic analysis of the activities of the tourism industry, as well as actual materials needed to solve the tasks. In the context of globalization and creativity of the economy, hyper-competition and deep metamorphoses that occur in the essence and content of business, it becomes obvious that the important factor in the successful functioning of a modern organization is its provision with an adequate system of strategic marketing planning, therefore, the process of forming a marketing strategy in the tourist business and its stages is characterized. The expediency of using the 7P marketing model for the development and promotion of the tourist product in the tourism business is justified. In accordance with this, it is considered that a high-quality tourist product is developed on the basis of consumer demand research, offered in the right place, targeted to specific segments of consumers, at affordable prices, competently and professionally presented at the market of tourist services and implemented with high-quality service. This can be achieved through a clear and consistent strategic marketing program. The strategic marketing program of a tourist company must reflect the demand and competitive situation on the market and describe immediate measures in the case of changes. A professionally developed marketing strategy allows tourist companies to counteract various environmental influences in the long term period. Therefore, the principles of forming a marketing strategy for a tourist company are highlighted. The possibilities of increasing the profitability of a travel company in the context of implementing a marketing planning strategy are studied. The importance of tourist products positioning in the formation of marketing strategy in tourism is determined. The methods of controlling the implementation of the strategy are offered. The perspective directions of further scientific researches in this direction are defined.

Keywords: tourism; strategy; business plan; strategic marketing planning. 